\title{
Tooth Extraction: A Systematic Revision
}

\begin{abstract}
Alvarenga $\mathrm{AF}^{1 *}$, Picinini $\mathrm{LS}^{2}$, Ferreira $\mathrm{AP}^{2}$ and de Oliveira $\mathrm{RG}^{2}$
${ }^{1}$ Dental Student at the School of Medical and Health Sciences of Juiz de Fora, Brazil

${ }^{2}$ Coordinator of the Postgraduate Program of Implant Dentistry of the School of Medical and Health Sciences of Juiz de Fora, Brazil
\end{abstract}

*Corresponding author: Altivo Ferraz Alvarenga, Dental Student at the School of Medical and Health Sciences of Juiz de Fora, Brazil, (Zip Code) CEP: 36016-290, Tel: +5532999614874; Email: altivoferraz@hotmail.com

\section{Review Article}

Volume 5 Issue 2

Received Date: March 26, 2020

Published Date: April 14, 2020

DOI: $10.23880 /$ oajds-16000248

\section{Abstract}

Introduction: Tooth extraction is a technique widely used in dentistry when dentists are faced with the impossibility of maintaining or restoring teeth in the oral cavity, resulting in physiologically induced bone resorption.

Aims: Verify the surgical technique of atraumatic tooth extraction by means of a systematic review of the literature.

Methods: Studies found in the Medline electronic databases were analyzed. In the search strategy, the following combinations of key words were used: ("atraumatic tooth extraction" AND "atraumatic tooth removal" AND "atraumatic extraction technique".)

Results: The eight articles that formed part of this review demonstrated that there was controversy in the results relative to the best technique for determining the decisive practice for treating the patient, which did not differ in the choice of the lower rate of post-extraction bone resorption.

Conclusion: There is still a lack of consistent scientific evidence for application of the surgical technique of choice.

Keywords: Tooth Extraction; Atraumatic Extraction Technique; Atraumatic Tooth Extraction

\section{Introduction}

Tooth extraction is a technique widely used in dentistry when dentists are faced with the impossibility of maintaining or restoring teeth in the oral cavity, in conditions that would be admissible for maintaining health, function and/ or esthetics. After tooth extraction, the alveoli heal without complications, however, associated with physiological and iatrogenic mechanisms, they show partial loss of alveolar bone as a natural, inevitable consequence, by means of traumas to the surrounding tissues. Since only one bony part will be remodeled, considering the impossibility of performing a completely atraumatic extraction, the possible exception of orthodontic extrusion is evident [1-7]. The compromised teeth are submitted to removal techniques using the proper instruments, pliers, elevators/luxators or a syndesmotome culminating in alveolar bone traumatism, considering that to rupture the periodontal ligament fibers in their movements in the horizontal direction, or in rotation, we have a significant expanse of bone available [8], and that would physiologically induce bone resorption due to the death of the structure histologically known as the lamina dura, resulting from the process arising from the loss of function, which corresponds to anchorage of the tooth in the alveolus [1].

In contemporary dentistry, it has been increasingly suggested that atraumatic procedures could contribute to maintenance of the alveolar ridge after extraction, mainly due to the possibility of rehabilitation with fixed and removable dental prostheses, including the placement of osseointegrated implants and preventing Osteonecrosis induced by bisphosphonates. For esthetic and functional 
rehabilitations after implant placement, it has been accepted in the literature that it is undoubtedly imperative to preserve the alveolar bone volume and favorable architecture of the alveolar crest [9]. In addition to the factor of prosthetic rehabilitation, the atraumatic technique for patients undergoing continuous chemotherapy and treatment for arterial pressure without immunosuppression, would be of great value as a feasible alternative way of performing tooth extraction, since there are reports in the literature in which regular tooth extraction practices in these patients resulted in Osteonecrosis induced by bisphosphonates [10].

For this purpose, it is necessary to evaluate which of the techniques available in the literature may predict the best results from the physiological point of view to prevent or limit post-extraction bone remodeling. In view of the foregoing, the aim of the present study was to verify, by means of a systematic review, which atraumatic extraction techniques are available at present.

\section{Methods}

\section{Search Strategies}

The most relevant studies originally published in English were analyzed, using the MedLine (National Library of Medicine e National Institutes of Health) electronic databases as reference. With the purpose of selecting the studies with the highest level of scientific evidence, we only contemplated clinical trials and descriptive studies.

In the present study, the following search strategy was used: "atraumatic tooth extraction" AND "atraumatic tooth removal" AND "atraumatic extraction technique". The inclusion and exclusion criteria were applied, based on the types of studies, language and type of intervention, considering the points raised in each item exposed (Chart 1). The search was continued in the references of the articles found to complement the summary of the studies.

\begin{tabular}{|c|c|}
\hline \multicolumn{2}{|c|}{ Inclusion Criteria } \\
\hline Study Design & Clinical trials and observational studies \\
\hline Patients & Adults \\
\hline Intervention & Atraumatic Extraction \\
\hline Languages & English \\
\hline \multicolumn{2}{|c|}{ Casclusion Criteria } \\
\hline Study Design & written, or inadequate. \\
\hline $\begin{array}{c}\text { Intervention } \\
\text { Application } \\
\text { Mode }\end{array}$ & $\begin{array}{c}\text { Onterventions in abstract } \\
\text { Main Clinical Outcomes }\end{array}$ \\
\hline \multicolumn{2}{c}{ Bone preservation } \\
\hline \multicolumn{2}{c}{ Successful extractions } \\
\hline
\end{tabular}

Chart 1: Inclusion and exclusion criteria applied for selecting studies.

\section{Results}

Initially, 22 studies involving atraumatic tooth extraction were identified. Figure 1 shows the Flow Diagram of selection of studies.

In Table 1, a summary of the studies selected and reviewed in the present study will be presented.

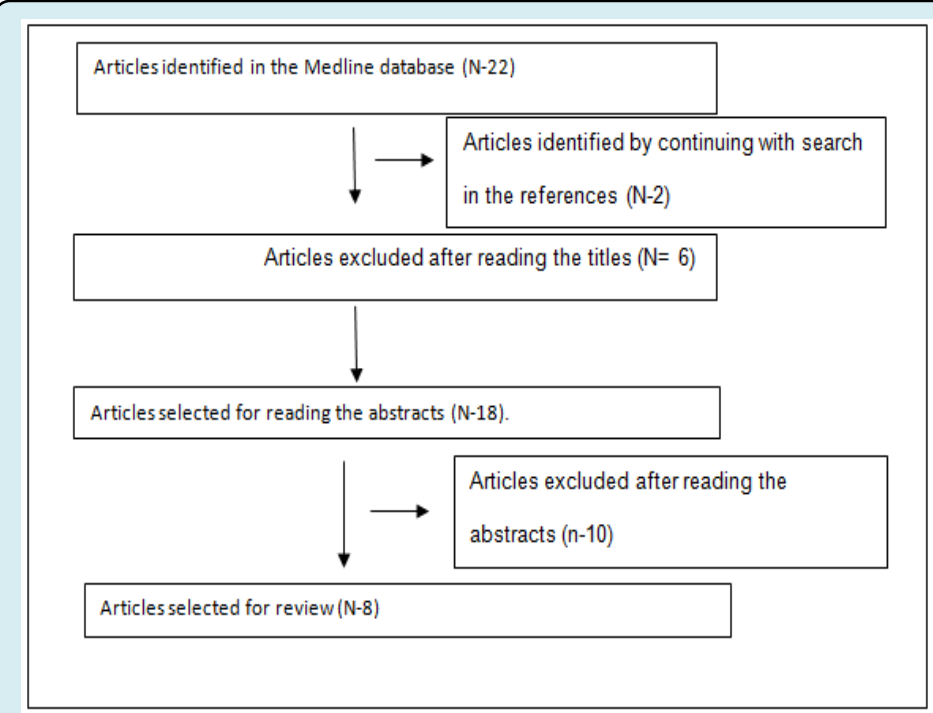

Figure 1: Flow Diagram of Selection of Studies. 
Open Access Journal of Dental Sciences

\begin{tabular}{|c|c|c|c|c|}
\hline & & & \multicolumn{2}{|l|}{ Outcomes } \\
\hline Studies & Sample & Intervention & Bone preservation & $\begin{array}{c}\text { Successful } \\
\text { extractions }\end{array}$ \\
\hline \multirow{5}{*}{$\begin{array}{l}\text { Blus C, } \\
\text { et al. } \\
{[11]}\end{array}$} & $\begin{array}{c}86 \text { patients (aged between } 26 \text { and } \\
77 \text { years of age). }\end{array}$ & \multirow{5}{*}{$\begin{array}{l}\text { Ultrasound } \\
\text { (piezoelectric } \\
\text { surgery) }\end{array}$} & & \multirow{5}{*}{$100 \%$} \\
\hline & 53 women & & & \\
\hline & 33 men & & - & \\
\hline & 30 root remainders & & & \\
\hline & 138 teeth & & & \\
\hline \multirow{5}{*}{$\begin{array}{l}\text { Muska } \\
\text { E, et al. } \\
\text { [8] }\end{array}$} & 72 patients & \multirow{5}{*}{ Benex } & & $83 \%$ teeth extracted. \\
\hline & $\begin{array}{l}25 \text { women (mean age } 53 \text { years - } \\
\text { age range from } 20 \text { to } 84 \text { years) }\end{array}$ & & & $83 \%$ of the roots. \\
\hline & $\begin{array}{c}47 \text { men (mean age } 51 \text { years }-17 \\
\text { to } 88 \text { ) }\end{array}$ & & - & Single root $=89 \%$ \\
\hline & 82 root remainders & & & Multiple roots $=43 \%$ \\
\hline & 29 teeth & & & \\
\hline \multirow{4}{*}{$\begin{array}{l}\text { Blus C, } \\
\text { et al. } \\
{[12]}\end{array}$} & 23 patients & \multirow{4}{*}{ Ultrasound. } & & \\
\hline & $\begin{array}{l}16 \text { women and } 7 \text { men (mean age } \\
\text { from } 37 \text { to } 77 \text { years) }\end{array}$ & & & \\
\hline & 12 root remainders & & - & $100 \%$ \\
\hline & 28 teeth & & & \\
\hline \multirow{4}{*}{$\begin{array}{l}\text { Crespi } \\
\text { R, et al. } \\
{[13]}\end{array}$} & 53 patients & \multirow{4}{*}{$\begin{array}{l}\text { Electric } \\
\text { hammer }\end{array}$} & Monoradicular Cavities $p>0.05$ & \\
\hline & $\begin{array}{c}31 \text { women and } 22 \text { men (mean age } \\
62.6 \text { years and age range from } 34 \\
\text { to } 76 \text { years) }\end{array}$ & & $\begin{array}{c}\text { Group A: Bone loss in maxillary } \\
\text { molar cavities (for mesial sites } 3.01 \\
\pm 0.76 \text { vs } 1.88 \pm 0.91 \mathrm{~mm} \text {, for distal } \\
\text { sites } 2.92 \pm 0.57 \text { vs } 1.67 \pm 0.66 \mathrm{~mm} \text { ) }\end{array}$ & \\
\hline & Not applicable & & Group B: $p>0.05$ & \\
\hline & 145 teeth & & & - \\
\hline \multirow{4}{*}{$\begin{array}{l}\text { Yalcin } \\
\text { S, et al. } \\
{[14]}\end{array}$} & 9 patients & \multirow{4}{*}{ Implant burrs } & & \\
\hline & $\begin{array}{l}7 \text { women and } 2 \text { men (age range } \\
\text { between } 24 \text { years and } 60 \text { years) }\end{array}$ & & & \\
\hline & Not applicable & & $100 \%$ & $100 \%$ \\
\hline & 9 teeth & & & \\
\hline \multirow{4}{*}{$\begin{array}{l}\text { Chen } \\
\text { Z, et al. } \\
\text { [15] }\end{array}$} & 15 patients & \multirow{4}{*}{ Implant burrs } & $\begin{array}{l}\text { Level of } 6 \mathrm{~mm} \text { (buccal: } \mathrm{P}=0.22 \text {, } \\
\text { lingual: } \mathrm{P}=0.21 \text {; without reduction } \\
\text { of HBT. HBT at } 0,1 \text { and } 2 \mathrm{~mm}(0.88 \pm \\
0.25 ; 0.48 \pm 0.28 \text { and } 0.33 \pm 0.17 \mathrm{~mm} \text {, } \\
\text { respectively, for vestibular). Lingual } \\
\text { side }(0.45 \pm 0.12,0.31 \pm 0.09 \text { and } \\
0.18 \pm 0.08 \mathrm{~mm})(\mathrm{P}<0.01) .\end{array}$ & \\
\hline & $\begin{array}{c}10 \text { women and } 5 \text { men (mean age } \\
49 \text { years and age range from } 28 \text { to } \\
70 \text { years) }\end{array}$ & & $\begin{array}{c}\text { VBH: } 0.74 \pm 0.32 \mathrm{~mm} \text { vestibular and } \\
0.40 \pm 0.17 \text { lingual. }\end{array}$ & \\
\hline & Not applicable & & $\begin{array}{c}\text { DIP of } 0.46 \pm 0.27 \text { and } 0.39 \pm 0.21 \\
\mathrm{~mm},(\mathrm{P}=0.35 \text {; for mesial and distal } \\
\text { regions. }\end{array}$ & \\
\hline & 17 teeth & & & - \\
\hline
\end{tabular}




\begin{tabular}{|c|c|c|c|c|}
\hline \multirow{4}{*}{$\begin{array}{c}\text { Regev } \\
\text { E, et al. } \\
{[16]}\end{array}$} & 10 patients & \multirow{4}{*}{$\begin{array}{l}\text { Orthodontic } \\
\text { elastic }\end{array}$} & \multirow{4}{*}{$100 \%$} & $\begin{array}{l}19 \text { roots exfoliated } \\
\text { spontaneously. }\end{array}$ \\
\hline & - & & & $\begin{array}{l}2 \text { roots, the forceps } \\
\text { were used }\end{array}$ \\
\hline & - & & & \\
\hline & 15 teeth & & & \\
\hline \multirow{4}{*}{$\begin{array}{c}\text { Crespi } \\
\text { R et al. } \\
\text { [17] }\end{array}$} & 156 patients & \multirow{4}{*}{$\begin{array}{l}\text { Electric } \\
\text { hammer }\end{array}$} & \multirow{4}{*}{$\begin{array}{l}\text { The surrounding tissues were } \\
\text { radiographically intact }\end{array}$} & \multirow{4}{*}{$100 \%$} \\
\hline & $\begin{array}{c}96 \text { men; } 60 \text { women Mean age from } \\
53.2 \pm 26.4 \text { years }\end{array}$ & & & \\
\hline & - & & & \\
\hline & 427 teeth & & & \\
\hline
\end{tabular}

Table 1: Summary of the studies and their main results involving the atraumatic extraction technique.

\section{Discussion}

The number of studies that deal with surgical treatment with maximum alveolar bone preservation after tooth extraction are limited in the literature, when desiring to ratify the atraumatic tooth extraction technique. Therefore, in the present study, a systematic review was conducted of clinical trials and observational studies about surgical treatment for atraumatic tooth extraction, in accordance with the principles of evidence-based dentistry, in which, the best evidence available in the literature must be used to help with the decision-making process. Traumatizing the alveolar bone in some way by means of the conventional extraction techniques using pliers, elevators and luxators, the term atraumatic extraction permeates the literature without ever having been clearly defined. This is due to the fact that there are no studies evaluating the rates and general limitations [8], being described as the least traumatic possible [11] or even as being quasi atraumatic extraction Blus C, et al. [12], reporting the attempt to perform more atraumatic tooth extraction [13], minimizing the risak of traumatizing the vestibular and lingual alveolar bone [14] or describing it as being minimally invasive [15]. These data are in agreement with the description of the process of the primary tooth exfoliation and its effect on (?) the periodontal ligament [16] and minimized trauma through a combination of techniques [17] culminating in the possibility of real use of the term, atraumatic extraction, as explained by the authors.

As described by Blus $\mathrm{C}$, et al. [11] in the piezoelectric and ultrasound techniques, the periodontal ligament fibers are cut at the coronal level of the alveolus, in a way similar to that as in the technique described by Crespi, et al. [17]. This also functions by separating the fibers in the coronal region of the root; the electric hammer is the device that has a periotome blade with a foot pedal control, operating at a mechanized speed. By means of combining them, atraumatic extraction is achieved. The periotome was described by Wang, et al. [18] as being capable of maximizing preservation of the alveolar bone, by applying minimal trauma on the periodontal tissues. Other authors have described that its use made it possible to perform atraumatic extraction [19]. However, with ultrasound it was necessary to use a straight or angled sindesmotome to obtain a deeper cut, to attain a maximum depth of $10 \mathrm{~mm}$ into the periodontal ligament, considering that the arrow-shaped tip was introduced into the sulcus to a depth of only 4 to $5 \mathrm{~mm}$ around the teeth, as opposed to the magnetic hammer that advanced apically in 2 $\mathrm{mm}$ increments. The two types did not differ from a surgery without periodontal flaps and without separating the gingiva from the teeth. Thereby, optimized esthetic results were obtained after dental implant placement.

In a study conducted by Blus C, et al. [12] and by Crespi R, et al. [13] they stated that piezoelectric surgery, ultrasound and the electric hammer, used respectively by the mentioned authors, generated minimal damage to the radicular bone and surrounding tissues. Therefore, irrespective of immediate implant placement or not, they obtained good healing results, which was one of the pillars of atraumatic tooth extraction. Bleeding during tooth extraction, in both types of techniques was limited, thus culminated in minimizing the surgical trauma and in achieving good preservation of the soft tissues.

In the search for an alternative to atraumatic extraction, Yalcin, et al. [14] described a technique for minimizing the damage caused to the bony walls, particularly the thin vestibular plates, considering the way in which the implant burrs tend to preferentially perforate the palatine bone wall, which are positioned in the root canals to make the root walls thinner thereby leading to an extraction achieved with using much less force. Nevertheless, Chen Z, et al. [15], determined the use of mesiodistal and buccolingual reference marks on the residual crown to mark the position of the implant, with an orifice being performed at the intersection of the two reference lines, using a high-speed handpiece with a round tipped burr in the direction of the axis of the tooth, without 
a periodontal flap. The osteotomy was performed directly through the central pathway and the remainder of the root complex, and thus the other aspects of the tooth were extracted in a minimally invasive manner. In their results it was found that the horizontal bone height undergoes the greatest changes when compared with the lingual bone heights. Similarly, the vertical vestibular bone height also undergoes greater changes than the lingual bone heights [20], making it possible to understand the predilection for perforating the palatine bone wall, as described by Yalcin S, et al. [14], seeing that in his study there was no explanation for the usability of perforation in the most palatine direction possible.

Based on the presupposition that according to Muska E, et al. [8], the term "atraumatic extraction" has never been clearly defined. In his article he describes that the only possible exceptions are the methods of extraction that apply an orthodontic force, of which the outcome consists of exfoliation rather than extraction of the tooth itself. Therefore, he reports the use of a system of tooth extraction-the Benex system - for the purpose of minimizing any trauma to the bone, by applying a force of traction along the axis of the root, resulting in rupture of the periodontal fibers and removal of the conical roots without bone expansion, with interest in the part of rehabilitation with implants. However, also by recognizing the conditions for preventing Osteonecrosis associated with Bisphosphonates. This information was in agreement with the aims of other authors Hoefert $S$ and Regev E $[9,16]$, who proposed an alternative tooth extraction technique that would avoid Osteonecrosis of the mandible, associated with bisphosphonate. This technique was based on the principle of the inclined plane in which an elastic is placed on the root so that the forces applied by the elastics are sufficient to cause destruction of the periodontal ligament and eruption of the tooth, without direct impact on the bone, thereby preventing bone exposure, confirmed by his results. In a longer period of observation of 9 months, these results showed no inflamed tissue or exposed bone in any of the cases.

\section{Conclusion}

This study found that there is still no exact definition of atraumatic tooth extraction. Nevertheless, further research on surgical techniques is required, because they continue to be an obstacle to the scientific community. In addition, further studies are needed to indicate which option would be the best alternative for the patient, dental surgeon, bone preservation and for effective tooth removal.

\section{References}

1. Van der Weijden F, Dell'Acqua F, Slot DE (2009) Alveolar bone dimensional changes of post-extraction sockets in humans: a systematic review. J Clin Periodontol 36(12): 1048-1058.

2. Mead SV (1954) Oral Surgery. $4^{\text {th }}$ (Edn.), St. Louis, MO: Mosby, pp: 450-573.

3. Hong B, Bulsara Y, Gorecki P, Dietrich T (2018) Minimally invasive vertical versus conventional tooth extraction: An interrupted time series study. J Am Dent Assoc 149(8): 688-695.

4. Thoma KH (1963) Oral Surgery. $4^{\text {th }}$ (Edn.), St. Louis, MO: Mosby, pp: 290-327.

5. Saund D, Dietrich T (2013) Minimally-invasive tooth extraction: doorknobs and strings revisited! Dent Update 40(4): 325-326.

6. Kruger GO (1964) Text book of OralSurgery. $2^{\text {nd }}($ Edn.), St. Louis, MO: Mosby, pp: 88-101.

7. Kotsakis G, Chrepa V, Marcou N, Prasad H, Hinrichs J (2014) Flapless alveolar ridge preservation utilizing the "socket-plug" technique: clinical technique and review of the literature. J Oral Implantol 40(6): 690-698.

8. Muska E, Walter C, Knight A, Taneja P, Bulsara Y, et al. (2013) Atraumatic vertical tooth extraction: a proof of principle clinical study of a novel system. Oral Surg Oral Med Oral Pathol Oral Radiol 116(5): 303-310.

9. Irinakis $\mathrm{T}$, Tabesh M (2007) Preserving the socket dimensions with bone grafting in single sites: an esthetic surgical approach when planning delayed implant placement. J Oral Implantol 33(3): 156-163.

10. Hoefert S, Grimm M, Sharghi F, Geist A, Krimmel M, et al. (2014) Atraumatic tooth extraction in patients taking bisphosphonates: a review of literature and experience with three cases. Oral Maxillofac Surg 18(3): 341-349.

11. Blus C, Szmukler-Moncler S, Khoury P, Orrù G (2015) Immediate implants placed in infected and noninfected sites after atraumatic tooth extraction and placement with ultrasonic bone surgery. Clin Implant Dent Relat Res 30: 355-363.

12. Blus C, Szmukler-Moncler S (2010) Atraumatic tooth extraction and immediate implant placement with Piezosurgery: evaluation of 40 sites after at least 1 year of loading. Int J Periodontics Restorative Dent 30(4): 355-363.

13. Crespi R, Capparé P, Crespi G, Gastaldi G, Gherlone EF (2017) Dimensional Changes of Fresh Sockets With Reactive Soft Tissue Preservation: A Cone Beam CT 
Study. Implant Dent 26(3): 417-422.

14. Yalcin S, Aktas I, Emes Y, Kaya G, Aybar B, et al. (2009) A technique for atraumatic extraction of teeth before immediate implant placement using implant drills. Implant Dent 18(6): 464-472.

15. Chen Z, Li J, Wang HL, Yu H (2019) Initial Bone Volume Changes after Immediate Implant Placement Associated with Filling the Gap Using Bovine Bone in Molar Sites. Int J Oral Maxillofac Implants 34(2): 521-528.

16. Regev E, Lustmann J, Nashef R (2008) Atraumatic teeth extraction in bisphosphonate-treated patients. J Oral Maxillofac Surg 66(6): 1157-1161.

17. Crespi R, Bruschi GB, Capparé P, Gherlone E (2014) The utility of the electric mallet. J Craniofac Surg 25(3): 793-
795.

18. Wang HL, Shotwell JL, Itose T, Neiva RF (2005) Multidisciplinary treatment approach for enhancement of implant esthetics. Implant Dent 14(1): 21-29.

19. Papadimitriou DE, Geminiani A, Zahavi T, Ercoli C (2012) Sonosurgery for atraumatic tooth extraction: a clinical report. J Prosthet Dent 108(6): 339-343.

20. Qabbani AA, Razak NHA, Kawas SA, Sheikh Abdul Hamid S, Wahbi S, et al. (2017) The Efficacy of Immediate Implant Placement in Extraction Sockets for Alveolar Bone Preservation: A Clinical Evaluation Using ThreeDimensional Cone Beam Computerized Tomography and Resonance Frequency Analysis Value. J Craniofac Surg 28(4): 318-325. 